\title{
Manichaean Eschatology: Gnostic-Christian Thinking about Last Things
}

The past decades have seen the publication of new Manichaean texts such as the Greek Mani-Codex and new editions of pivotal eschatological texts such as the Coptic Sermon on the Great War and Mani's Šābuhragān. When combined with previously discovered Manichaean texts and, for instance, polemics from the Church Fathers, these texts throw a new light on Manichaean eschatology. The present chapter aims at presenting some of these new insights, while stressing that Manichaean eschatology, both according to Western and Eastern sources, awards the central position in eschatological events to Jesus.

\section{Introduction}

The newly-discovered texts have revolutionised our understanding of Manichaeism. Up to the 1980s, many scholars saw Manichaeism as an offshoot of Iranian religious traditions, in particular because of its "dualism" and a number of its eschatological

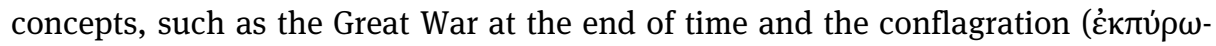
oıs) of the world through fire. Since the discovery of the Mani Codex, however, we know for certain that the prophet Mani, the founding father of Manichaeism who was born in 216 CE in present-day Iraq and died in 276 or $277,{ }^{1}$ was raised in a Jewish-Christian community of Elkesaites. This means that the young Mani grew up in a sort of kibbutz among Jews who believed Jesus to be the Messiah and venerated a certain Elchasai as the final prophet. Not Iranian, but Jewish and Christian ideas

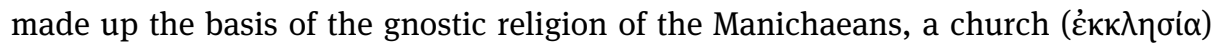
which spread from Mesopotamia as far as Roman Africa and Spain in the West and China in the East. Astonishingly, recently small communities have been discovered near Quanzhou on the South China-coast who continue to venerate Mani as the Buddha of Light. ${ }^{2}$

From the Greek Mani Codex we also learn that Mani was an eschatological prophet and that his first disciples considered themselves to live in apocalyptic

1 According to Sayed Hasan Taqizadeh, the most likely date is February 26, 277; see Taqizadeh and Henning, "The Dates of Mani's Life,” 107. For discussion, see e.g. Böhlig and Asmussen, Manichäismus, 309-310; Böhlig, "Manichäismus," 30; Sundermann, "Studien zur kirchengeschichtlichen Literatur," 367-369.

2 For general introductions to Mani and Manichaeism, see e.g. Samuel N. C. Lieu, Manichaeism in the Later Roman Empire; Gardner and Lieu, Manichaean Texts; van Oort, "Mani;" van Oort, "Manichaeism." On Quanzhou, see esp. Lieu's contributions to Medieval Christian and Manichaean Remains. 
times. ${ }^{3}$ We find the same in Mani's own writings, in particular the so-called Šābuhragān, composed to convert šāh-in-šāh Šābuhr I. ${ }^{4}$ We gain the same impression from a third text, the Sermon on the Great War, which has been transmitted in Coptic and was discovered in Egypt at the end of the 1920s. ${ }^{5}$ These texts can be characterised as strongly eschatological.

\section{The Eschatological Cologne Mani Codex}

The first source of crucial importance in this context is the Mani Codex that was discovered in Egypt shortly before 1970. Due to its acquisition by the University of Cologne, it is usually referred to as the Cologne Mani Codex, or $C M C .^{6}$ On each of the tiny parchment codex' very small pages $(4.5$ to $3.5 \mathrm{~cm})$ we find about 23 lines written in Greek majuscules. The codex contains a biography of the young Mani in the form of accounts by his earliest disciples. Mani grew up in a baptising sect whose members hailed the Jewish-Christian prophet Elchasai ${ }^{7}$ as their founder

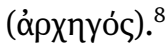

Reading the $C M C$ one is reminded of Rudolf Bultmann's Theologie des Neuen Testaments. ${ }^{9}$ If I may call to mind its opening sentences: "Jetzt ist die Zeit gekom-

3 Koenen, "Manichaean Apocalypticism." This groundbreaking article remains the text for research on Manichaean eschatology; the present overview draws heavily on it as well.

4 The most recent and best edition of all the fragments, with English translation, is MacKenzie's, "Šābuhragān," (1979; 1980). But see also, for instance, Manis kosmogonische Šābuhragān-Texte, ed. Hutter, and German translations of essential parts of the Middle Persian text in Böhlig and Asmussen, Manichäismus, 234-239.

5 The key new edition is Studies in the Sermon on the Great War, ed. Pedersen, 7-42. See also Pedersen's doctoral dissertation "Studies in the Sermon on the Great War," and his "Der große Krieg." The still often quoted editio princeps was by Polotsky, Manichäische Homilien, 7-42. Partial English translation (by Iain Gardner) with focus on the Sermon's final passages in Gardner and Lieu, Manichaean Texts, 221-226; partial German translation in Böhlig and Asmussen, Manichäismus, 234-239.

6 First preliminary edition ("Vorbericht”): Henrichs and Koenen, "Ein griechischer Mani-Codex;" editio princeps of $C M C$, c. 1-72.7, in: ZPE 19, 1-85 (with extensive commentary); of CMC, c. 72. 899.9, in: ZPE 32, 87-199 (with very extensive commentary); of CMC, c. 99.10-120, in: ZPE 44, 201318 (with very extensive commentary); of $C M C$, c. 121-192 in: ZPE 48, 1-59. An ample commentary on the final section has been published by Römer, Manis frühe Missionsreisen. A complete edition was published by Koenen and Römer, Der Kölner Mani-Kodex: Über das Werden seines Leibes. Moreover, a diplomatic text has been edited by Koenen and Römer, Der Kölner Mani-Kodex: Abbildungen und diplomatischer Text.

7 For the main facts (with relevant literature) on Elchasaios (or Alchasai, Elkesai, Elxaios, Elxai), who is said to have received the revelation written about in the Book of Elchasai in Mesopotamia in 116-117, see my German entry "Elkesaiten” (English "Elkesaites") "Elkesaites," 416.

8 CMC c. 94. 10-11 (=Der Kölner Mani-Kodex, ed. Koenen and Römer [dipl. text], 186).

9 Bultmann, Theologie des Neuen Testaments. 
men! Die Gottesherrschaft bricht herein! Das Ende ist da!” According to the New Testament scholar Rudolf Bultmann and others, Jesus was an eschatological prophet and he calls on his hearers to make a decision ("Der Ruf zur Entscheidung"). The crucial sign of the eschaton is the appearance of the prophet Jesus and his call.

The $C M C$ argues the same, and describes the Life of Mani as part of the history

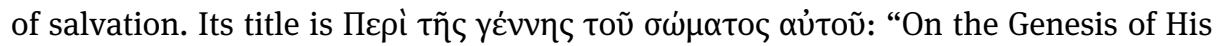
Body." "Body" means both Mani's physical body and his church. The CMC is not the work of one author, but comprises excerpts from the testimonies of Mani's first disciples. Just as the evangelists gave their account of Jesus' deeds and words (cf. Acts 1:1), in this codex Mani's disciples give their account of his life and teachings. The disciples include Salmaios the Ascetic; Baraies the Teacher; Timotheos; Abjesous the Teacher; Innaios the brother of Zabed; Za[cheas?]; Kustaios, the Son of the Treasure of Life. We will encounter Kustaios again below as the author of the Sermon on the Great War.

The CMC's central message is the revelation of $\tau \dot{\alpha}$ yevó $\mu \varepsilon v \alpha$ ("what happened")

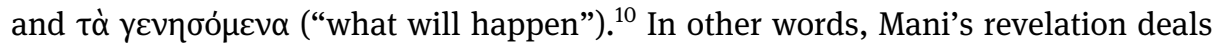
with the entire past, which includes the termination of the original separate state of "light and darkness", their ensuing mixture, and the first wars: and it deals with the future, the real है $\sigma \chi \alpha \tau \alpha$, including the Great War, the Last Judgment, and the restoration of the original separate states of "light and darkness". Evil will be enclosed in

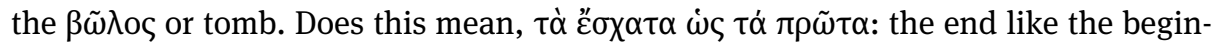
ning? Not quite, for as we will see, there are important differences.

Let us first examine how Mani is depicted as an eschatological prophet in the CMC. He tells the members of the community of Jewish baptists that their daily

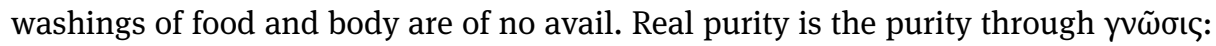
"It is the separation of light from darkness, death from life, living waters from turbid ones" (84); "[...] you [should keep] the commands of the Saviour (= Christ) [so that] he may redeem [your] soul from [destruction] and from (85) perdition.” Mani then recounts, in this same excerpt from Baraies the Teacher, that some accepted his words ("they treated me as prophet and teacher", 86), but that the majority rejected him. They said: "Is he the one concerning whom our teachers prophesied when they said, 'A young man will [rise up from] our [midst] and will come [forward] as a new [teacher] (87) to call into question our whole doctrine, just as our forefathers have spoken of the Rest of the Garment?"' The forefathers meant here are the Jewish

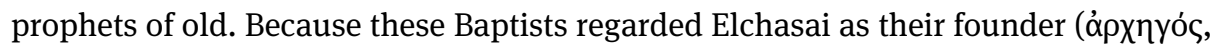
94), we may explain the rather enigmatic expression "the rest of the garment" ( $\dot{\eta}$

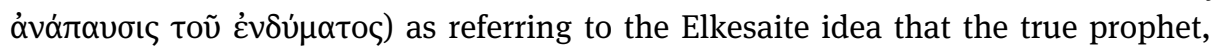

10 Cf. CMC, 26.1-2 (= Der Kölner Mani-Kodex, 52, ed. Koenen and Römer). According to the latter, one may also translate (cf. e.g. Gardner and Lieu, Manichaean Texts, 51): "[...] those things which had happened or were to happen [...]." Or, in rather archaic English: "that which will come to pass." 
having dressed himself in the "garments" of the body of the successive incarna-

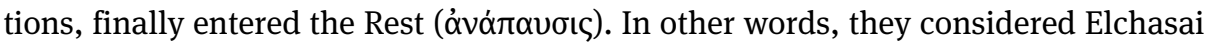
the final prophet. Now, however, some of them wondered whether Mani could be part of this tradition: was he the final prophet? The majority of the Baptists denied this and regarded him as one of the apocalyptic pseudo-prophets, and even tried to kill him. ${ }^{11}$

We see here that both Mani's opponents, as well as his disciples, stood in the Jewish-Christian tradition of the prophet Elchasai, who received the apocalyptic revelation written in the Book of Elchasai in Mesopotamia in the year 116 or $117 .^{12}$ The difference is that the disciples considered Mani to be the final prophet. It could be that they already used the expression "seal of the prophets", although this title is transmitted only in medieval Muslim sources such as the writings of al-Biruni and al-Sharastānī and thus may be an expression exclusive to Muslim writers. ${ }^{13}$ Anyhow, in the $C M C$, Mani and his importance are discussed in eschatological terms. After a number of (previously completely unknown!) Jewish apocalypses ${ }^{14}$ and also some passages from the apostle Paul (2 Cor. 12; Gal. 1) have been quoted, it states that Mani's revelation is the final one and that his disciples became "the seal of his apos-

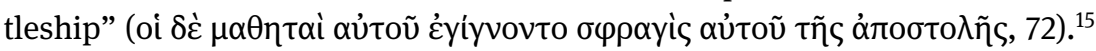

In the Coptic Kephalaia, texts on Manichaean doctrine that seem to have been directly inspired by Mani's own teachings, it is emphatically stated that Mani was sent to the last generation. ${ }^{16}$ He was not only Jesus' final prophet, but also the Paraclete. ${ }^{17}$ In the words of Mani as transmitted by his disciple Timotheos in the $C M C$, his function was "to scatter the bread on my people". ${ }^{18}$ Even Augustine says that some of Mani's disciples considered his name to be Mannichaios (with double N), i.

11 For the further development of the controversy, see CMC, c. 94-106 (= Der Kölner Mani-Kodex, c. 186-210, ed. Koenen and Römer,). A fine analysis of context and background can be found in Reeves, "The 'Elchasaite' Sanhedrin."

12 Cf. above, note 7.

13 See e.g. Stroumsa, "Seal of the Prophets;" Colpe, Das Siegel der Propheten.

14 See e.g. Gruenwald, "Manichaeism and Judaism;" Reeves, Heralds of that Good Realm.

15 Thus the reading according to Koenen and Römer, Der Kölner Mani-Kodex, 50. Their diplomatic edition (Der Kölner Mani-Kodex: Abbildungen und diplomatischer Text, c. 142, ed. Koenen and Römer) reads $\sigma \varphi \rho \alpha y \varepsilon ı$. For the expression, one may compare the apostle Paul in 1 Cor. 9:2.

16 Kephalaia, c. 179, ed. Polotsky and Böhlig, 16-17. Translation: Polotsky and Böhlig, vol. 1, 179:

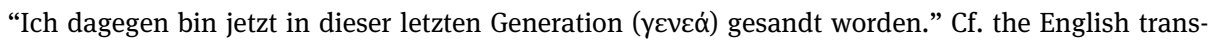
lation by Gardner, Kephalaia, 189: "Furthermore, I myself was sent now, in this last generation."

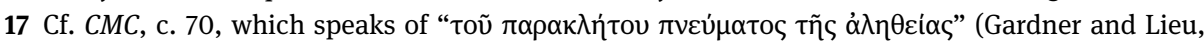
Manichaean Texts, 58: "[...] through the Paraclete, the spirit of truth"). On Mani as the Paraclete promised in Jn 14, see e.g. Sundermann, "Paraklet;" van Oort, "The Paraclete Mani."

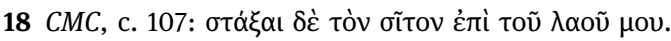


e., the shedder of manna. ${ }^{19}$ Jewish tradition has it that the miracle of manna would be repeated at the end of the world..$^{20}$

To summarise: the $C M C$ depicts Mani's life as the beginning of eschatology. With his deeds and words, the last days are imminent. His life initiates the final wars of "light and darkness", Good against Evil. In all of these features, he is heir to the Jewish eschatological expectations in general, and of the Jewish-Christian ones in particular.

\section{Mani’s Šābuhragān and his Disciple Kustaios' Sermon on the Great War}

We can identify the same characteristic of Mani's mission in the fragments of the Šābuhragān, the Middle Persian text he composed for Šābuhr I. ${ }^{21}$ The work's aim was to win the (already more or less convinced) Zoroastrian king over to Manichaeism, and it is for this reason that the Manichaean deities and other aspects of the worlds of "light and darkness" bear Persian names. Several of the Šăbuhragān's sections are deeply influenced by the Synoptic Apocalypse (Mk. 13; Mt. 24; Lk. 21) and the eschatological content of the twenty-fifth chapter of Matthew. ${ }^{22}$

This essential feature of the Šābuhragān is also clearly reflected in the Coptic Sermon on the Great War. ${ }^{23}$ The term "Great War" seems to be Iranian, ${ }^{24}$ but most of the sermon is clearly inspired by Jewish and Christian traditions ${ }^{25}$ (including, perhaps, the Apocalypse of John ${ }^{26}$ ). The Sermon or Logos is said to be composed by

19 Augustine, De haeresibus, 46.1: [...] Mannichaeum uocant, quasi manna fundentem.

20 Cf. e.g. the annotations of Henrichs and Koenen to CMC, 107, in: ZPE 44, 265 n. 361, and the still leading study of Borgen, Bread from Heaven.

21 See for MacKenzie's text edition and translation, note 4, above.

22 This last aspect is specifically discussed in Hutter, "Mt 25:31-46 in der Deutung Manis.”

23 See for the editions of Pedersen and Polotsky, note 5, above.

24 As repeatedly stressed by Widengren; see already his Mani und der Manichäismus, 70, 150, n. 3. 25 See in particular the analysis of Pedersen, Studies in the Sermon on the Great War, and the brief annotations in his text edition in The Sermon on the Great War, ed. Pedersen, 7-42.

26 Cf. Pedersen, in particular his diagrams of biblical allusions and quotations in Studies in the Sermon on the Great War, 53-64 (which are followed by thorough analyses of the available material, 64-79). As regards the Apocalypse, Pedersen concludes (75-79) that its use by the Manichaeans is "possible", although one should bear in mind (1) that an expression such as "the cup of wrath" (The Sermon on the Great War, ed. Pedersen, 7, 1. 25,) or "the second death" (Kephalaia, ed. Polotsky and Böhlig, 104.106.150) could have been derived also from other (Jewish) texts, and (2) that the Manichaean New Testament seems to have consisted only of "the Gospel” and "the Apostle" (i.e., Paul) (cf. e.g. Tardieu, "Principes de l'exégèse manichéenne”). For the "possible” reminiscences of Apocalyypse in the Sermon, see also the corresponding annotations in The Sermon on the Great War, ed. Pedersen, 7, 1. 14. 
Kustaios, ${ }^{27}$ one of the authors of the $C M C$. The Sermon speaks of persecutions, in all probability those under Bahrām II (277-293) and perhaps Hormizd II (303-310). ${ }^{28}$ It was originally written at the end of the third or the beginning of the fourth century, somewhere in Mesopotamia and probably in East-Aramaic. ${ }^{29}$

The Logos deals with Manichaean eschatology in great detail. It opens with apocalyptic predictions about a time of disaster: robberies, wars, battles; death, hunger, refugees; and so on. ${ }^{30}$ Then follows a discussion of the wars of the saviours against Error $(\pi \lambda \alpha \dot{v} \eta)$ : Zarathustra against the pre-Zoroastrian religion; Jesus against the errant Jews; Mani against the magi. ${ }^{31}$ According to the Sermon (like the $\mathrm{CMC}$ ), the final cycle of history begins with Mani, whose mission is painted as ending in new disaster and error, and the coming of the Great War. ${ }^{32}$ Weeping is a strong characteristic of eschatological feelings; one may compare Jesus, Enoch (in the Apocalypse of Enoch ${ }^{33}$ ), Ezra (in 4 Ezra): all true prophets are full of tears. ${ }^{34}$ After the Great War comes the peaceful rule of the Great King. ${ }^{35}$ This rule lasts from the end of the war until - within Mani's own generation - the Antichrist comes. ${ }^{36}$ During the Great King's peaceful rule, the end is like the beginning and even trees will speak. ${ }^{37}$ As is the case with the pseudo-prophets in the $\check{S} \bar{a} b u h r a g a \bar{n},{ }^{38}$ the Antichrist will be defeated quickly. ${ }^{39}$ Then comes Jesus the Splendour (called Xradešahr in the Šābuhragān, i.e., the God of the World of Wisdom or Nous ${ }^{40}$ ) and the Last Judg-

27 See e.g. the page headings in The Sermon on the Great War, ed. Pedersen, 27, 31, 35, 39 [the last two are missing in Polotsky's edition]; cf. Pedersen, Studies in the Sermon on the Great War, 87-93. 28 Cf. e.g. Pedersen, Studies in the Sermon on the Great War, 87.

29 E.g. Pedersen, Studies in the Sermon on the Great War, 80-87; Pedersen, "Der große Krieg," 62. 30 Studies in the Sermon on the Great War, ed. Pedersen, 8, 6-10, 28. It is not easy to make a clearcut division of the text. For convenience's sake, I mainly follow Koenen's global division (Koenen, “Manichaean Apocalypticism," 298-307). For Pedersen's perhaps more sophisticated summary of the Sermon's sections, see his Studies in the Sermon on the Great War, 170-171.

31 The Sermon on the Great War, ed. Pedersen, 10, 1. 28-31.

32 The Sermon on the Great War, ed. Pedersen, 12-21, 27.

33 Cf. $C M C$, c. $58 \mathrm{ff}$.

34 On weepings, see in particular Pedersen, Studies in the Sermon on the Great War, 113-115 and 200-222. Pedersen inter alia considers the possibility that the eschatological weepings of the Manichaeans are connected with their Bema-festival and also that they possessed "books of weepings”, one of which (The Weeping) circulated under Mani's name.

35 Studies in the Sermon on the Great War, ed. Pedersen, 21, 28-33. It is important to note that in the Elchasaite tradition (cf. e.g. Epiphanius, Panarion, 19.3.4) the Great King is Christ.

36 The Sermon on the Great War, ed. Pedersen, 34.

$37 \mathrm{Cf}$. CMC, 10.1ff. and 98.9ff. for the speaking of trees (thus preventing the suffering of the divine Light). One may compare Testament of Abraham 3, 1-3 and the Genesis Apocryphon found in cave 1 of Qumran.

38 Šābuhragān, 1-10, transl. MacKenzie, 504-505.

39 Cf. Studies in the Sermon on the Great War, ed. Pedersen, 28, 1. 4.

40 Cf. e.g. “Šābuhragān,” 17, transl. MacKenzie, 505. 
ment. ${ }^{41}$ The description of the Judgment is similar to that found in Matthew 25: the sheep (i.e., the Manichaean Elect and the worthy Auditors) will be separated from the goats. ${ }^{42}$ Under the rule of Jesus the Splendour, gods, angels and the Elect will live together in a new golden age. ${ }^{43}$ Again, the trees will be green and talk; all evil will be removed from the world and mankind will listen to the true religion. ${ }^{44}$ Then follows the dissolution and destruction of the world. Through the Porter or

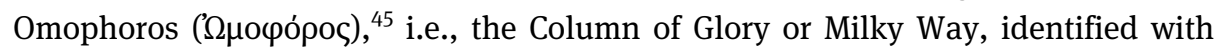
the cosmic Jesus), the sons of the Living Spirit will leave the world. ${ }^{46}$ Primal Man will unveil his face and attract them to himself in Paradise. ${ }^{47}$ The whole earth will

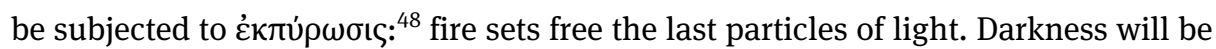
imprisoned in a $\beta \tilde{\omega} \lambda$ os or Tomb. ${ }^{49}$

41 The Sermon on the Great War, ed. by Pedersen, 35-38. Cf. "Šābuhragān," 42ff., transl. MacKenzie, $504 \mathrm{ff}$.

42 On the (fairly complicated) question of the use of Mt. 25 in Mani's and Kustaios' text repectively, see Pedersen, Studies in the Sermon on the Great War, $127 \mathrm{ff}$.

43 Studies in the Sermon on the Great War, ed. by Pedersen, 39, 1. 1-18. Cf. "Šābuhragān,” 130 ff., transl. MacKenzie, 508ff.

44 An interesting feature in this context is that the believers, if they wish so, "will strip themselves of their body, and receive the victory with him [i.e., Jesus], and find the road levelled from him up to the kingdom of life" (Manichaean Homilies, ed. Pedersen, 39, 15-18). Another is that, according "Šābuhragān," 130ff., transl. MacKenzie, 509, "when god Xradešahr [i.e., Jesus] will care for the world, then will day, month and year come to an end [...]." The last feature is also stressed in other texts, for instance, 2 Henoch 17.

45 Only named once in the Sermon as we have it (The Sermon on the Great War, ed. Pedersen, 40, 1. 6), but several times in, for instance, the Kephalaia. As his name ("one who bears on the shoulders") indicates, this figure has also been identified as Atlas, but as far as I can see he has another role. In an explanatory note to his translation of Keph. 25, 23-25, Böhlig, Manichäismus, 328, note 11, remarks: "Die Säule der Herrlichkeit ist nicht mit dem fünften Sohn des Lebendigen Geistes zu identifizieren. Weil dieser, der Atlas bzw. Omophoros, den Kosmos trägt, heißt er so. Weil die Säule der Herrlichkeit aber das Licht aus der Welt emporträgt, hat die den Beinamen 'der große Omophoros' bekommen. 'Groß' dient hier zur Differenzierung.” Clackson and others in Dictionary of Manichaean

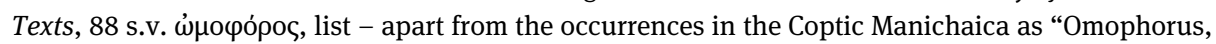
Atlas, Burden-bearer, Porter" - the texts in which it is used in epithets of the Column of Glory, the Perfect Man and in epithets of the Sons of the Living Spirit.

46 Studies in the Sermon on the Great War, ed. by Pedersen, 39, 1. 18 - 41, 1. 11. One may compare "Šābuhragān," 159ff., transl. MacKenzie, 511ff.

47 Koenen, "Manichaean Apocalypticism," 304, interestingly compares the Sermon's account that the appearance of First or Original Man results in the destruction of the world with Apoc. 20:11: on the appearance of "the white throne and the One sitting upon it", "the earth and the heavens fled from his presence, and there was no place for them".

48 Here I use, following Koenen, "Manichaean Apocalypticism," 304, the general eschatologicalapocalyptical term, though it should be noted that - as far as I am aware - the term is not used in Greek or (as a loan word) Coptic Manichaica.

49 Strictly speaking, the term $\beta \tilde{\omega} \lambda$ os does not appear in the Sermon, but cf. Pedersen, Studies in the Sermon on the Great War, 379ff. Still the best study on the Manichaean $\beta \tilde{\omega} \lambda$ os is Decret, "Le 'globus horribilis' dans l'eschatologie manichéenne” (repr. in Decret, Essais sur l'Église manichéenne, 7-13). 
Curiously, this $\beta \tilde{\omega} \lambda$ os is situated in the middle of the New Aion, both structures having already been built at the time of the creation of the world. May we call this some sort of supra-lapsarism ${ }^{50}$ Or absolute determinism ${ }^{51}$ Paradise as the outer sphere and the New Aion as the inner sphere encircle the $\beta \tilde{\omega} \lambda$ os. ${ }^{52}$ In the New Aion,

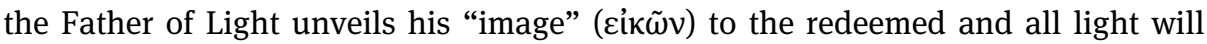
merge into Him. ${ }^{53}$

Indeed, Kustaios' Logos speaks of the New Paradise and the Eternal Paradise. The Eternal Paradise appears to refer to the original kingdom of God the Father of Greatness and New Paradise to the New Aion of Primal Man or Christ. It is not wholly clear whether the New Aion will last forever, like the Father's eternal Paradise. ${ }^{54}$ If not, one may speak of some Messianic intermezzo, ${ }^{55}$ after which Christ "will hand over the Kingdom to God the Father" (1 Cor. 15:24-28).

Apart from the $\beta \tilde{\omega} \lambda$ os (for the incarceration of the male demons and evil doers), several texts probably including Kustaios' Sermon; cf. Manichäische Homilien, ed. Polotsky, 41 note to line 6; Pedersen, Studies in the Sermon on the Great War, 379; Manichaean Homilies, ed. Pedersen, 41 also mention the tó $\varphi$ os (for the incarceration of the female ones).

50 The subject of supra- (and infra-) lapsarism has been much discussed in Calvinist dogmatics. See e.g. Barth, Kirchliche Dogmatik, 136ff. Interestingly, Berkouwer, Divine Election, 254, with regard to the supra- and infralapsarianism discussion asks "whether theology has not become a gnosis which can never become quite transparent to the Church and can never really affect the Church's belief" (his italics).

51 As a rule, Greek and other Eastern church fathers accused Mani and his followers of (absolute) determinism. See e.g. Klein, Die Argumentation in den griechisch-christlichen Antimanichaica, passim, and the fine discussion (with ample references to texts and studies) in Pedersen, Demonstrative Proof in Defence of God, 173ff.

52 Graphically visualized, the $\beta \tilde{\omega} \lambda$ os is also the lowest place.

53 In the words of Kustaios (Studies in the Sermon on the Great War, ed. Pedersen, 41, 1. 14-16): "The veils will be rolled back and gathered, and he will unveil his image for them. All the light will submerge into him." Cf. for background e.g. Pedersen, Studies in the Sermon on the Great War, 394-395 and - in particular for the picture of the veil and the revelation of the Father - Pedersen, The Veil and the Revelation (with specific reference to Revelation 20:4 and Matthew 5:8 as its possible background c.q. parallels).

54 As stated above, it is - like the $\beta \tilde{\omega} \lambda$ o - "built" at the time of the creation of the world. On this and other activities of the "Great Builder" or "Great/First Architect", see e.g. Kephalaia, ed. Polotsky and Böhlig, 82, 8-12 and 118, 8-12.

55 The term (in the sense that Christ's incarnation and subsequent kingdom was God's temporary "emergency measure" in reaction to sin and the Fall) was coined and advocated in particular by the Utrecht theologian Arnold A. van Ruler in his extensive dogmatic writings, to begin with in his Groningen dissertation "De vervulling der wet”. The term was taken up by e.g. Jürgen Moltmann, but the meaning the latter attributed to the term differed from Ruler's. 


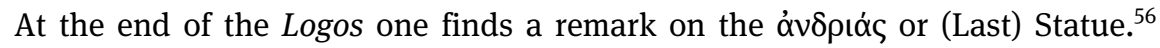
Unfortunately the passage is damaged. From other sources ${ }^{57}$ we know that this

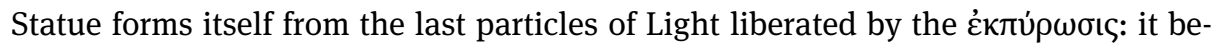
comes "the Perfect Man”. In all likelihood, this term is reminiscent of Eph 4:13 and thus refers to Jesus. ${ }^{58}$

\section{Concluding Remarks}

My overview is indeed a brief one that could be elaborated with many details. ${ }^{59}$ What strikes me in particular is the evident Judaeo-Christian substratum underlying many features of Manichaean eschatology. Evidently, this derives above all from Mani's own orgins in a Jewish-Christian kibbutz of Elkesaites.

It would be possible to provide a different description of Manichaean eschatology, ${ }^{60}$ and even to present an account featuring a dizzying number of names derived from Persian and Chinese languages. ${ }^{61}$ These are found, however, in texts that

56 Manichäische Homilien, ed. Polotsky, 41 l. 21, who translates "Ur[mensch]" and in a note remarks: "Auch nach den Kephalaia soll der Urmensch im Neuen Äon 'der ápxпyó seiner Brüder' sein;" Studies in the Sermon on the Great War, ed. Pedersen, p. 41 1. 21, with references to Kephalaia, c. 28.34-c. 29.4 and c. 54.19-24, ed. Polotsky and Böhlig, for the eschatological role of the Last Statue.

57 E.g. the Kephalaia; see all places indicated in Kephalaia, ed. Gardner, 300 s.v. "Last Statue;" cf. Clackson et al., Dictionary of Manichaean Texts, 61.

58 Cf. e.g. Stroumsa, “Aspects de l'eschatologie manichéenne,” 173, who also refers to Psalm-Book

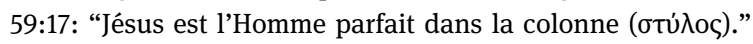

59 Such as, for instance, the curious teaching that the world fire will last for exactly 1468 years. Perhaps this idea is borrowed from Egyptian thinking: a Sothis period of 1461 years plus an eschatological "year week" of seven years. See e.g. Ogden, "The 1468 Years of the World-Conflagration in Manichaeism," 105, who for the apocalyptic “week" refers to 4 Ezra 7:43 in particular. His opinion is endorsed by, a.o., Stroumsa, “Aspects de l'eschatologie manichéenne,” 167, note 20; Koenen, “Manichaean Apocalypticism,” 316, 321-326; Sundermann, "Manichean Eschatology,” 572a/63. But see also Stocks, "Manichäische Miszellen II," who refers to the chronographic works of Julius Africanus and Hippolytus: according to Africanus, Jesus' resurrection happened in the year 5532, while the world will last for 7000 years. In this way, the eschatological period after Jesus' resurrection is 1468 years.

60 A highly original description of Manichaean eschatology, stressing both its Jewish-Christian and Gnostic (mainly Nag Hammadi) affinities, has been provided by Stroumsa, “Aspects de l'eschatologie manichéenne” (repr. in Stroumsa, Savoir et Salut, 259-273). Gardner, "The Eschatology of Manichaeism" offers a detailed and highly reliable account on the basis of Western (mainly the Kephalaia) and a number of Eastern sources. More general accounts are provided by Sundermann, "Manichaean Eschatology" (now in his Manichaica Iranica, 1.59-72, with bibliography and addenda) and in the less reliable (mainly while superannuated) overview by Jackson, "A Sketch of the Manichaean Doctrine.”

61 See e.g. Durkin-Meisterernst, Dictionary of Manichaean Texts, and Mikkelsen, Dictionary of Manichaean Texts. 
are both much younger and much more syncretistic than the texts discussed above. In the Šăbuhragān we hear Mani's ipsissima verba and, to a considerable extent, the same goes for the Logos and the CMC.

The crucial point is that Manichaeism was not an offshoot of Iranian thought, but a genuine Gnostic-Christian religion: gnostic in the sense that its central message is that the Nous ${ }^{62}$ rescues the Psyche from the Hyle, and Christian, because in essence all Saviour figures in the Manichaean myth are representations of Christ. ${ }^{63}$

\section{Bibliography}

\section{Abbreviations}

ZPE Zeitschrift für Papyrologie und Epigraphik, ed. Reinhold Merkelback and Ludwig Koenen. Bonn: Habelt, 1967 -.

\section{Primary Sources}

Kephalaia. Edited by Hans Jakob Polotsky and Alexander Böhlig. Stuttgart: Kohlhammer, 1940.

The Kephalaia of the Teacher. Edited by lain Gardner. Vol. 37, Nag Hammadi and Manichaean Studies. Leiden: Brill, 1995.

Der Kölner Mani-Kodex (P. Colon. inv. nr. 4780). Edited by Albert Henrichs and Ludwig Koenen. Zeitschrift für Papyrologie und Epigraphik 19 (1975): 1-85; 32 (1978): 87-199; 44 (1981): 201318; 48 (1982): 1-59.

Der Kölner Mani-Kodex: Abbildungen und diplomatischer Text. Edited by Ludwig Koenen and Cornelia Römer. Vol. 35, Papyrologische Texte und Abhandlungen. Bonn: Habelt, 1985.

Der Kölner Mani-Kodex: Über das Werden seines Leibes. Kritische Edition aufgrund der von A. Henrichs und L. Koenen besorgten Erstedition. Edited by Ludwig Koenen and Cornelia Römer. Vol. 14, Abhandlungen der Rheinisch-Westfälischen Akademie der Wissenschaften, Sonderreihe Papyrologica Coloniensia. Opladen: Westdeutscher Verlag, 1988.

Manichäische Homilien. Edited by Hans Jakob Polotsky. Stuttgart: Kohlhammer, 1934.

Manichaean Texts from the Roman Empire. Edited by lain Gardner and Lieu N. C. Samuel. Cambridge: Cambridge University Press, 2004.

Mani's Šäbuhragān. Edited by David Neil MacKenzie. Bulletin of the School of Oriental and African Studies 42 (1979): 500-534; 43 (1980): 288-310.

62 I.e., in essence, the revealing Wisdom or Gnosis which comes from the spiritual and eternal world and liberates from the temporal world of matter. On the varied aspects of the "Nou" in Manichaeism, see e.g. Tongerloo and Oort, The Manichaean NOUS.

63 See above for (in any case!) the eschatological figures of Jesus the Splendour sive Xradešahr; the Omophoros; Primal Man; and the Perfect Man. For more eschatological representations of Jesus, see e.g. Rose, Die manichäische Christologie, esp. 132-140 for his analysis of Mani's Šābuhragān and Kustaios' Logos. 
Manis kosmogonische Šäbuhragān-Texte. Edition, Kommentar und literaturgeschichtliche Einordnung der manichäisch-mittelpersischen Handschriften M 98/99 I und M 7980-7984. Edited by Manfred Hutter. Vol. 21, Studies in Oriental Religions. Wiesbaden: Harrassowitz, 1992.

The Sermon of the Great War. Edited by Nils Arne Pedersen. In Manichaean Homilies. With a Number of hitherto unpublished Fragments, 7-45. Vol. 2, Corpus Fontium Manichaeorum, Series Coptica. Turnhout: Brepols, 2006.

\section{Secondary Literature}

Barth, Karl. Kirchliche Dogmatik. Vol. 2, 2. Die Offenbarung Gottes. Zollikon: Evangelischer Verlag, 1942.

Berkouwer, Gerrit Cornelis. Divine Election. Grand Rapids: Eerdmans, 1960.

Böhlig, Alexander. "Manichäismus.” Theologische Realenzyklopädie. Vol. 22, edited by Gerhard Müller et al., 22-45. Berlin: De Gruyter, 1992.

Böhlig, Alexander, and Jes Peter Asmussen. Die Gnosis. Vol. 3. Der Manichäismus. Zürich: Artemis Verlag, 1980.

Borgen, Peder. Bread from Heaven. An Exegetical Study of the Concept of Manna in the Gospel of John and the Writings of Philo. Leiden: Brill, 1965.

Bultmann, Rudolf. Theologie des Neuen Testaments. Edited by Otto Merk. 7th ed. Tübingen: Mohr, 1977.

Clackson, Sarah, Erica Hunter, Samuel N. C. Lieu, and Mark Vermes, eds. Dictionary of Manichaean Texts. Vol. 1. Texts from the Roman Empire. Vol. 2, Corpus Fontium Manichaeorum, Subsidia. Turnhout: Brepols, 1998.

Colpe, Carsten. Das Siegel der Propheten. Historische Beziehungen zwischen Judentum, Judenchristentum, Heidentum und frühem Islam. Vol. 3, Arbeiten zur neutestamentlichen Theologie und Zeitgeschichte. Berlin: Institut Kirche und Judentum, 1989.

Decret, François. Essais sur l'Église manichéenne en Afrique du Nord et à Rome au temps de saint Augustin. Recueil d'études. Vol. 47, Studia ephemeridis “Augustinianum”. Rome: Institutum Patristicum Augustinianum, 1995.

Decret, François. “Le 'globus horribilis' dans l'eschatologie manichéenne. D’après les traités de saint Augustin." In Mélanges d'histoire des religions offerts à Henri-Charles Puech, edited by Suzanne Lassier, 487-492. Paris: Presses Universitaires de France, 1974.

Durkin-Meisterernst, Desmond, ed. Dictionary of Manichaean Texts. Vol. 3, 1. Texts from Central Asia and China (Manichaean Texts in Middle Persian and Parthian). Corpus Fontium Manichaeorum, Subsidia 3, 1. Turnhout: Brepols, 2004.

Gardner, lain. “The Eschatology of Manichaeism as a Coherent Doctrine." Journal of Religious History 17, no. 3 (1993): 257-273.

Gruenwald, Ithamar. "Manichaeism and Judaism in Light of the Cologne Mani Codex." Zeitschrift für Papyrologie und Epigraphik 50 (1983): 29-45.

Henrichs, Albert, and Ludwig Koenen. "Ein griechischer Mani-Codex (P. Colon. inv. nr. 4780)." Zeitschrift für Papyrologie und Epigraphik 5 (1970): 97-216.

Hutter, Manfred. “Mt 25:31-46 in der Deutung Manis." Novum Testamentum 33, no. 3 (1991): 276282.

Jackson, A. V. Williams. "A Sketch of the Manichaean Doctrine Concerning the Future Life." Journal of the American Oriental Society 50 (1930): 177-198.

Klein, Wassilios W. Die Argumentation in den griechisch-christlichen Antimanichaica. Vol. 19, Studies in Oriental Religions. Wiesbaden: Harrassowitz, 1991. 
Koenen, Ludwig. "Manichaean Apocalypticism at the Crossroads of Iranian, Egyptian, Jewish and Christian Thought." In Codex Manichaicus Coloniensis. Atti del Simposio Internazionale (Rende-Amantea 3-7 settembre 1984), edited by Luigi Cirillo and Amneris Roselli, 285-332. Cosenza: Marra Editore, 1986.

Lieu, Samuel N. C. Manichaeism in the Later Roman Empire and Medieval China. Vol. 63, Wissenschaftliche Untersuchungen zum Neuen Testament. 2nd ed. Tübingen: Mohr, 1992.

Lieu, Samuel N. C., Lance Eccles, Majella Franzmann, lain Gardner, and Ken Parry. Medieval Christian and Manichaean Remains from Quanzhou (Zayton). Vol. 2, Corpus Fontium Manichaeorum, Series Archaeologica et Iconographica. Turnhout: Brepols, 2012.

Mikkelsen, Gunner B., ed. Dictionary of Manichaean Text. Vol. 3, 4. Texts from Central Asia and China (Manichaean Texts in Chinese). Corpus Fontium Manichaeorum, Subsidia. Turnhout: Brepols, 2006.

Ogden, Charles J. "The 1468 Years of the World-Conflagration in Manichaeism." In Dr. Modi Memorial Volume. Papers on Indo-Iranian and Other Subjects written by Several Scholars in Honour of Jivanji Jamshedij Modi, 102-105. Bombay: The Fort Printing Press, 1930.

Oort, Johannes van. "Elkesaiten.” In Religion in Geschichte und Gegenwart. Vol. 2, edited by Hans Dieter Betz et al., 1227-1228. Tübingen: Mohr, 1999.

Oort, Johannes van. "The Paraclete Mani as the Apostle of Jesus Christ and the Origins of a New Christian Church." In The Apostolic Age in Patristic Thought, edited by Anthony Hilhorst, 139157. Leiden: Brill, 2004.

Oort, Johannes van. "Mani”; "Manichaeism." In Dictionary of Gnosis and Western Esotericism. Vol. 1, edited by Wouter J. Hanegraaf, 756-757; 757-765. Leiden: Brill, 2005.

Oort, Johannes van. "Elkesaites," in Religion Past \& Present, vol. 4, edited by Hans Dieter Betz et al., 416. Leiden: Brill, 2008.

Pedersen, Nils Arne. Studies in the Sermon on the Great War. Investigations of a Manichaean-Coptic Text from the Fourth Century. Aarhus: Aarhus University Press, 1996.

Pedersen, Nils Arne. "Der große Krieg - ein Hauptthema manichäischer Frömmigkeit." Hallesche Beiträge zur Orientwissenschaft 26 (1998): 59-72.

Pedersen, Nils Arne. Demonstrative Proof in Defence of God: A Study of Titus of Bostra's Contra Manichaeos. The Work's Sources, Aims and Relations to its Contemporary Theology. Vol. 56, Nag Hammadi and Manichaean Studies. Leiden: Brill, 2004.

Pedersen, Nils Arne. "The Veil and the Revelation of the Father of Greatness." In "In Search of Truth": Augustine, Manichaeism and other Gnosticism. Studies for Johannes van Oort at Sixty, edited by Jacob Albert van den Berg, Annemaré Kotzé, Tobias Nicklas and Madeleine Scopello, 229-234. Vol. 74, Nag Hammadi and Manichaean Studies. Leiden: Brill, 2011.

Reeves, John C. "The 'Elchasaite' Sanhedrin of the Cologne Mani Codex in Light of Second Temple Jewish Sectarian Sources." Journal of Jewish Studies 42, no. 1 (1991): 68-91.

Reeves, John C. Heralds of that Good Realm: Syro-Mesopotamian Gnosis and Jewish Traditions. Vol. 41, Nag Hammadi and Manichaean Studies. Leiden: Brill, 1996.

Römer, Cornelia E. Manis frühe Missionsreisen nach der Kölner Manibiographie. Textkritischer Kommentar und Erläuterungen zu p. 121-p. 192 des Kölner Mani-Kodex. Vol. 24, Abhandlungen der Nordrhein-Westfälischen Akademie der Wissenschaften, Sonderreihe Papyrologica Coloniensia. Opladen: Westdeutscher Verlag, 1994.

Rose, Eugen. Die manichäische Christologie. Vol. 5, Studies in Oriental Religions. Wiesbaden: Harrassowitz, 1979.

Ruler, Arnold A. van. De vervulling der wet: een dogmatische studie over de verhouding van openbaring en existentie. Nijkerk: Callenbach, 1947.

Stocks, Hermann. "Manichäische Miszellen II: Eine neue Erklärung der 1468 Jahre des manichäischen Weltbrandes." Zeitschrift für Religions- und Geistesgeschichte 3, no. 3 (1951): 258-261. 
Stroumsa, Guy G. “Aspects de l'eschatologie manichéenne." Revue de l'Histoire des Religions 198, no. 2 (1981): 163-181.

Stroumsa, Guy G. "Seal of the Prophets: the Nature of a Manichaean Metaphor." Jerusalem Studies in Arabic and Islam 7 (1986): 61-74.

Stroumsa, Guy G. Savoir et Salut: Traditions juives et tentations dualistes dans le christianisme ancien. Paris: Cerf, 1992.

Sundermann, Werner. "Manichean Eschatology." In Encyclopedia Iranica. Vol. 8, edited by Ihsān Yāršătir, 569-575. New York: Encyclopaedia Iranica Foundation, 1992.

Sundermann, Werner. "Der Paraklet in der ostmanichäischen Überlieferung." In Manichaica Iranica. Ausgewählte Schriften von Werner Sundermann. Vol. 2, edited by Christiane Reck, Dieter Weber, Claudia Leurini, and Antonio Panaino, 813-825. Vol. 89, Serie orientale Roma. Rome: Istituto Italiano per l'Africa e l'Oriente, 2001.

Sundermann, Werner. "Studien zur kirchengeschichtlichen Literatur der iranischen Manichäer III." In Manichaica Iranica. Ausgewählte Schriften von Werner Sundermann. Vol. 1, edited by Christiane Reck, Dieter Weber, Claudia Leurini and Antonio Panaino, 357-423. Vol. 89, Serie orientale Roma. Rome: Istituto Italiano per l'Africa e l'Oriente, 2001.

Taqizadeh, Sayed Hasan, and Walter Bruno Henning. “The Dates of Mani's Life.” Asia Maior N. S. 6 (1957): 106-121.

Tardieu, Michel. "Principes de l'exégèse manichéenne du Nouveau Testament." In Les règles de l'interprétation, edited by Michel Tardieu, 123-146. Paris: Cerf, 1987.

Tongerloo, Alois van, and Johannes van Oort, eds. The Manichaean NOUS. Proceedings of the International Symposium organized in Louvain from 31 July to 3 August 1991. Leuven and Turnhout: Belgian Center for Manichaean Studies / Brepols, 1995.

Widengren, Geo. Mani und der Manichäismus. Stuttgart: Kohlhammer, 1961. 